children's literature was its animated Disney version (and the proliferation of picturebooks it inspired), which "“infantilize[d]' the tale type" (16) by turning it into a cautionary tale about the importance of obeying authority.

While by no means exhaustive (nor purporting to be), the richly varied anthology - yet another testament to Zipes' abilities as researcher, editor, writer, and translator (the majority of translations from German, Italian, and French are his) - is sure to generate interest in this tale type, and become a springboard for future scholarly outings into this stimulating and fairly unexplored field. Zipes' prose is characteristically fluent, comprehensible, and oftentimes even conversational ("Hmm, this might make for a Harry Potter novel!", 63), which makes it accessible to a wide readership. This thought-provoking and visually appealing book is likely to acquire most devotees among folklorists, fairy-tale scholars, students (the variety and organisation of the materials make it especially suited for classroom use), and story-lovers at large, who are sure to enjoy these tales that "make us aware that magic matters, no matter what its substance may be, no matter what form it takes" (7).

Nada Kujundžić

\title{
Confronting Cultures
}

Giedrè Jankevičiūtė \& V. Geetha. 2017. Another History of the Children's Picture Book: From Soviet Lithuania to India. Chennai, India: Tara Books in association with the Lithuanian Culture Institute. 176 pp. ISBN 978-93-83145-45-4

DOI: $10.21066 /$ carcl.libri.2017-06(01).0011

Unusual combinations such as this will surely provoke many confused looks, since it seems difficult at first to connect terms such as "Soviet Lithuania", "India" and “children's picture books". However, Giedrè Jankevičiūtė and V. Geetha present us with an overview of Soviet children's picture books and their influence on two different cultures through this exceptional book full of wonderful illustrations. "Taken together, Indian and Lithuanian experiences help us rethink the global culture of the picture book: they focus on developments that are not often recounted in standard picture book histories, or even in scholarly literature" (5).

This compelling book emerged from an exhibition of children's books from Soviet Lithuania hosted by the publisher, Tara Books, in Chennai. The book is divided into two parts: the first one, entitled "Children's Picture Books from the Soviet Union: The View from India", puts the Indian experience with Soviet picture books in the spotlight. The second part focuses on the influence of illustrations in children's picture books in Soviet Lithuania. Each part is divided into several shorter chapters which concentrate on different aspects of children's picture books, and their influence on Indian and Lithuanian culture of that period.

The first part begins with a chapter called "The Enduring Appeal of Soviet Children's Books". Serving as an introduction, it explains that Soviet picture books were a window into Soviet children's way of life. Indian children gained the impression that Soviet children had a perfect life - with plenty of opportunities and different clubs offered by the Communist Party of the Soviet Union. What they did not see was the Communist propaganda hidden 
behind appealing words and stunning artwork. After the introductory chapter, the book continues with three short essays (chapters). "Soviet Books for India: A Brief History and Some Reflections" is the title of the second chapter and the first essay mentioned by the authors in the introduction. It deals with the historical connections between the Soviet Union and India, and describes how Soviet books, music and art came to India. One especially interesting experience comes from N. Dharmarajan, who explains the process of translating books from Russian into Tamil. Soviet picture books were often not only translated, but also modified to fit the local context. They became famous in India because they were not only modestly priced, but also available in multiple languages, unlike American and British picture books which were quite expensive and offered only in English. The chapter finishes with a historical overview of the Soviet influence on Indian culture and education. Conveniently, the following chapter is entitled "The Soviet Experiment with Education and Children's Book Publishing". It builds on the previous chapter and gives a detailed analysis of the Soviet model of education and children's book publishing. According to the authors, the Soviet model of education was greatly influenced by the Bolsheviks: "[E]ducation was assigned a transformative role: henceforth, schools would be spaces, of not only learning and instruction, but veritable nurseries for 'growing' and nurturing "small comrades"' (27). Not only education, but also publishing for children was adapted to the goal of "nurturing small comrades" with topics that fitted the needs of Communist society. The third chapter, "The Soviet Picture Book for Children: Some Thoughts on its History and Aesthetics”, introduces the term 'New Economic Policy'. Soviet picture books from the New Economic Policy era provided illustrations that promoted movement, energy, dynamics, and excitement. Often, the images were essential to the meaning of the story. The chapter gives a thorough overview of the topics of picture books, their ideologisation, propaganda, and changes reflecting those in the Soviet government and the world from the 1920 s to the 1980s. As the concluding chapter of the first part of the book, "The Soviet Example and Indian Concerns" explains why everything mentioned in the previous chapters is of great importance to Indian culture. At the end of the first part, there is a page of selected references.

The second part of the book is called "Children's Book Illustrations from Soviet Lithuania". Similar to the previous part, it begins with an introductory chapter that presents the history of Lithuania and its dubious relationship with the Soviet Union ("Art and Publishing in Lithuania: From Independence to Soviet Rule"). Once it became annexed to the Soviet Union, literature and publishing flourished, but with consequences - authors were obliged to obey the State and a lot of their work was censored or marked as "not suitable". "Children's Literature in Soviet Lithuania: Response to Socialist Realism" is the next chapter. Most of the books published in the post-war decade had naturalistic artwork with "perfect" Communist children, living in a "perfect" society, as the main characters. This chapter also mentions some famous authors from other nations that were translated into Russian (Charles Dickens, Selma Lagerlöf, Hans Christian Andersen, Mark Twain). Still, Lithuanian children read not only books and picture books, but also periodicals and journals which offered both entertainment and ideology. The richly illustrated text describes in great detail two of them - Genys and Lietuvos pionierius. Another way of influencing the childhood of many Lithuanians was through different clubs, summer camps, institutions 
and schools, which are described at the end of the chapter. The final part of the chapter is dedicated to children's publisher Aldona Liobyte (1915-1985). In a manner similar to the previous chapters, which describe the development of picture books until the 1950s, the next two chapters focus on the following decades.

“The Dynamic 1960s: New Directions in Children's Books' Illustrations" presents the 1960 s as the age of modernisation and change. Illustrators of that time started using different means of expression, such as photomontage and colour paper-cuts. Illustrations were the perfect addition to a text and the change in art form and topics through the decades could easily be seen. Even though there was a never-ending battle against the strict censorship imposed by the regime, the old themes remained the same, neatly wrapped into a new, modern design. Besides being influenced by Western countries which brought many new forms of art into Soviet picture books (e.g. Pop Art), the artists decided to rediscover the past through "Primitive Modern" art. The chapter finishes with some thoughts on the impact of illustrations on young readers and the artists themselves. The chapter "Children's Books' Illustration in an Era of Stagnation: 1970s and After" presents the 1970s and 1980s as a time of inactivity, in which people drew back into their private lives. Still, the era of stagnation inspired two important developments: the translations of children's books from Polish, Czech, Finnish and Swedish, and the foundation of Vyturys, a specialist publisher of children's books in 1985. This chapter also mentions two new illustrators that emerged from the era - Stasys Eidrigevičius and Kęstutis Kasparavičius. The final and shortest chapter of the book is "Postscript from the Past", which delivers a conclusion on the second part of the book. It deals with the effect of illustrations on people living in Soviet Lithuania at that time. In addition, it offers some engaging illustrations as examples of the importance of Soviet picture books and their art.

From the very first glance, the book is compelling. The front cover illustration and the back cover and endpaper illustrations are borrowed from different picture books mentioned in the book, which perfectly encapsulates the subject. Through such marvellous covers, the authors immediately manage to draw the readers' interest. The text is very clear, and the facts are presented in detail and supported by illustrations. Even though the book uses specialist terms on occasions, the coherent text and supporting illustrations ensure that it is generally easy to read. I would recommend this book to all types of readers - scholars, teachers, and students interested in this field. The authors can certainly be credited for merging seemingly disparate things, and bringing some of the tough, intriguing past into the present.

Katarina Kokanović

\section{O pripovjednoj slikovnici}

Smiljana Narančić Kovač. 2015. Jedna priča - dva pripovjedača: slikovnica kao pripovijed. Zagreb: ArTresor naklada. 447 str. ISBN 978-953-8012-04-4

DOI: 10.21066/carcl.libri.2017-06(01).0012

U svojoj knjizi posvećenoj pripovjednoj slikovnici Smiljana Narančić Kovač uvodi nas u detaljno razmatranje slikovnice kao zasebne umjetničke knjige te pokazuje kako je tu naizgled vrlo jednostavnu književnu vrstu ipak potrebno pomnije proučiti i analizirati. Smiljana Narančić Kovač predaje na Učiteljskome fakultetu Sveučilišta u Zagrebu gdje, 